\title{
Triticum mosaic virus: A New Virus Isolated from Wheat in Kansas
}

Dallas L. Seifers and T. J. Martin, Professors, Kansas State University, Agricultural Research Center-Hays, Hays 67601-9228; Tom L. Harvey, Professor, Department of Entomology, Kansas State University, Manhattan 66506; John P. Fellers, United States Department of Agriculture-Agricultural Research Service-PSERU, Department of Plant Pathology, Manhattan, KS 66506; James P. Stack and Marietta Ryba-White, Department of Plant Pathology, Kansas State University, Manhattan; Steve Haber, Cereal Research Centre, Agriculture \& Agri-Food Canada, Winnipeg, Manitoba, Canada; and Oleg Krokhin, Victor Spicer, Nicole Lovat, Andrej Yamchuk, and Kenneth G. Standing, Department of Physics and Astronomy, University of Manitoba, Winnipeg, Manitoba, Canada

\begin{abstract}
Seifers, D. L., Martin, T. J., Harvey, T. L., Fellers, J. P., Stack, J. P., Ryba-White, M., Haber, S., Krokhin, O., Spicer, V., Lovat, N., Yamchuk, A., and Standing, K. G. 2008. Triticum mosaic virus: A new virus isolated from wheat in Kansas. Plant Dis. 92:808-817.

In 2006, a mechanically-transmissible and previously uncharacterized virus was isolated in Kansas from wheat plants with mosaic symptoms. The physiochemical properties of the virus were examined by purification on cesium chloride density gradients, electron microscopy, sodium dodecyl sulfate polyacrylamide gel electrophoresis (SDS-PAGE), sequencing of the nucleotides and amino acids of the coat protein, and immunological reactivity. Purified preparations contained flexuous, rod-shaped particles that resembled potyviruses. The coat protein was estimated from SDS-PAGE to have a mass of approximately $35 \mathrm{kDa}$. Its amino acid sequence, as deduced from DNA sequencing of cloned, reverse-transcribed viral RNA and separately determined by time-of-flight mass spectrometry, was most closely related (49\% similarity) to Sugarcane streak mosaic virus, a member of the Tritimovirus genus of the family Potyviridae. The virus gave strong positive reactions during enzyme-linked immunosorbent assays using polyclonal antibodies raised against purified preparations of the cognate virus but gave consistent negative reactions against antibodies to Wheat streak mosaic virus (WSMV), other wheat potyviruses, and the High Plains virus. When the virus was inoculated on the WSMV-resistant wheat cv. RonL, systemic symptoms appeared and plant growth was diminished significantly in contrast with WSMV-inoculated RonL. Taken together, the data support consideration of this virus as a new potyvirus, and the name Triticum mosaic virus (TriMV) is proposed.
\end{abstract}

Additional keywords: temperature-sensitive resistance

Wheat (Triticum aestivum L.) is an important crop in Kansas and in other areas of the Great Plains of North America. Many viruses have been reported to infect wheat in Kansas and surrounding states, including Agropyron mosaic virus (AgMV; 29), Wheat American striate mosaic virus (WASMV; 34), Barley yellow dwarf mo-

Corresponding author: Dallas L. Seifers E-mail: dseifers@ksu.edu

Contribution No.08-70-J from the Kansas Agricultural Experiment Station.

Research in Kansas was partially funded by a grant from the Kansas Wheat Commission. Research in the Manitoba time-of-flight mass spectrometry laboratory was supported by a grant from NSERC (Canada).

The capsid protein amino acid sequence determined by time-of-flight mass spectrometry is deposited as SwissProt Accession No. A4KZ49 and the deduced amino acid sequence determined from the nucleotide sequence and is deposited as GenBank Accession No. EF 173696.

Accepted for publication 15 January 2008.

doi:10.1094/PDIS-92-5-0808

(c) 2008 The American Phytopathological Society

locations in Kansas. The agent of this apparent infection subsequently was transmitted mechanically to wheat seedlings. Several possibilities might account for the apparent viral-like symptoms of the WSMV-resistant wheat. For one, sufficiently sustained elevated temperatures caused the resistance to WSMV to breakdown $(40,42)$. A second possibility was that HPV or capable HPV variants had infected these wheat lines (30). A final possibility was that another virus distinct from WSMV or HPV had induced the symptoms. Neither of these first two possibilities, however, were supported by serological analyses using enzyme-linked immunosorbent assay (ELISA). Also, sodium dodecyl sulfate polyacrylamide gel electrophoresis (SDS-PAGE) failed to identify the coat protein band of WSMV, HPV, or HPV variants in many of the symptomatic wheat samples. Therefore, it was hypothesized that another virus was causing the infection. Evidence is presented here that a new, uncharacterized virus, with the proposed name Triticum mosaic virus (TriMV), was responsible for the systemic mosaic symptoms.

saic virus (BYDV; 28), High Plains virus (HPV; 15,37), Wheat soilborne mosaic virus (3), Wheat spindle streak mosaic virus (53), Wheat yellow head virus (WYHV; 38), and Wheat streak mosaic virus (WSMV; 39,52). Among these viruses, WSMV is chronic and widespread, routinely causing severe losses in wheat in Kansas $(23,50,57)$.

Commercial wheat cultivars and advanced breeding lines that are resistant to WSMV have been developed recently $(9,41,42)$. The WSMV resistance of these lines is temperature sensitive: the resistance is effective at a constant temperature of $18^{\circ} \mathrm{C}$ in a growth chamber but ineffective when temperatures is maintained at a constant $24^{\circ} \mathrm{C}(40,42)$. Under field conditions, where diurnal temperature variation is present, such resistance has proved effective $(40,42)$. The recently developed cv. RonL incorporates this resistance and has been released commercially (42).

During 2006, RonL and other lines with temperature-sensitive WSMV resistance developed systemic virus-like symptoms in the field. These symptomatic wheat plants were not geographically localized and were found in plots at several different

\section{MATERIALS AND METHODS}

Virus source and maintenance. The unknown virus-like agent U06-123 (subsequently referred to as TriMV) was isolated from KS06HW79 wheat on 25 April 25 2006 at the Kansas State University Agricultural Research Center-Hays (KSUARCH), located in Hays, KS. The Sidney 81 isolate of WSMV was collected near Sidney, ND, in 1981 by W. G. Langenberg (40). Both viruses were propagated separately by mechanically inoculating the wheat cv. Tomahawk at the single-leaf stage using the leaf-rub technique (42), with a $1: 10(\mathrm{wt} / \mathrm{vol})$ ratio of tissue to extract buffer. Extract buffer used contained $0.02 \mathrm{M}$ potassium phosphate buffer, $\mathrm{pH} 7$, with $1 \mathrm{~g}$ of 600-mesh Crystolon flour B per $100 \mathrm{ml}$ of extract. Following inoculation, the plants were held in a greenhouse under natural lighting and rated for symptoms at 14 to 21 days post inoculation (DPI) with a temperature range of 18 to $27^{\circ} \mathrm{C}$. The following reference viruses were maintained in frozen $\left(-80^{\circ} \mathrm{C}\right)$ leaf tissue: Maize dwarf mosaic virus (MDMV; 
31), Sugarcane mosaic virus strain MDB (SCMV-MDB; 33), Johnsongrass mosaic virus (JGMV; 32), Brome mosaic virus (BMV; 45), Sorghum mosaic virus (SrMV) (PV 51), HPV (Kansas isolate) $(44,46)$, Foxtail mosaic virus (FoMV; 35), and AgMV (PV 75) (29).

Field sampling. Leaves were collected from field-grown, symptomatic wheat from Ellis, Ford, Ness, Osborne, Pawnee, and Thomas Counties in Kansas, and symptomatic barley samples were collected in Ellis County at the KSU-ARCH. The leaf samples were placed in selfsealing plastic bags and placed on ice in transit to the laboratory. Samples were weighed and frozen for later analysis.

Plant dry weight analysis. Two metal flats $(21$ by $31 \mathrm{~cm})$ were filled with $4.9 \mathrm{~kg}$ of Harney clay loam soil (fine montmorillonitic, mesic Typic Argiustoll). Six rows were formed in the flats with the centers of each row $45 \mathrm{~mm}$ apart. The first and sixth rows were filler, treated as border rows, and planted with cv. Tomahawk. Rows 2, 3,4 , and 5 were randomly planted with two rows of cv. RonL and two rows of KS96HW10-3, both of which are resistant to WSMV (42). Each of these rows was planted with 15 seeds sieved with 17-by3.6-mm openings to uniform size. Following planting, the flats were held in a greenhouse under natural lighting and temperature ranges of 17 to $24^{\circ} \mathrm{C}$ until the plants reached the single-leaf stage. The plants in each row then were thinned to 10 of uniform size and then the first leaf was mechanically inoculated, as above, with extract prepared from Tomahawk infected with TriMV. The experimental design was a randomized complete block, with the location of treatments randomly assigned to the four rows in each flat. Treatments consisted of two rows of each cultivar, one row healthy and one row inoculated. Following inoculation, one flat was moved to a growth chamber set at $18^{\circ} \mathrm{C}$ with $8 \mathrm{~h}$ of illumination $\left(250 \mu \mathrm{Es}^{-1} \mathrm{~m}^{-2}\right)$ per day and the second flat moved to a growth chamber at $24^{\circ} \mathrm{C}$ with the same lighting conditions. At 7, 14, 21, and 28 DPI, the plants were rated for symptom expression. Following symptom rating at $28 \mathrm{DPI}$, the plants in the rows representing each treatment were harvested (cut off at ground level), weighed, and put into individual, labeled paper bags. The bags were placed in a forced-air oven set at $69^{\circ} \mathrm{C}$ for 7 days and then weighed again. The analysis of variance for the dry weight data was conducted using SAS (version 8; SAS Institute, Cary, NC) and significant treatment effects were determined using the least significance difference test at $P=0.05$. The experiment was repeated three times on consecutive days.

Virus purification, antiserum preparation, and antiserum sources. The U06123 isolate of TriMV was purified for production of antibodies as previously de- scribed for AgMV (29) and WYHV (38). Systemically infected wheat leaves were ground in a mortar and pestle in grinding buffer (GB; $0.1 \mathrm{M}$ diammonium citrate, $0.25 \%$ [vol/vol] 2-mercaptoethanol, $0.1 \%$ [vol/vol] sodiumdiethyldithiocarbamate, and $1.0 \%$ polyvinylpyrrolidone [molecular weight 40,000], pH 6.5) at a ratio of $1 \mathrm{~g}$ of leaf tissue per $7 \mathrm{ml}$ of the GB. The extract was filtered through cheesecloth and brought to a final $4 \%$ (vol/vol) Trition X100. The extract was centrifuged at 23,700 $\times g$ for $25 \mathrm{~min}$ at $5^{\circ} \mathrm{C}$, the supernatant was transferred into tubes for the $50 \mathrm{Ti}$ rotor, and each tube was underlaid with $2 \mathrm{ml}$ of $0.988 \mathrm{M}$ sucrose (made in GB) and then centrifuged for $2 \mathrm{~h}$ at $85,000 \times g$ at $5^{\circ} \mathrm{C}$. The supernatant was discarded and pellets resuspended in $3.5 \mathrm{ml}$ of GB and centrifuged for $20 \mathrm{~min}$ at $31,000 \times \mathrm{g}$. The supernatant then was transferred to SW 50.1 centrifuge tubes and underlaid with $1.0 \mathrm{ml}$ of $2.330 \mathrm{M}$ and $0.5 \mathrm{ml}$ of $3.297 \mathrm{M} \mathrm{CsCl}$. The interfaces between the 2.330 and $3.297 \mathrm{M} \mathrm{CsCl}$ and the supernatant appeared at 16 and $7 \mathrm{~mm}$, respectively, from the bottom of the tube. The tubes then were centrifuged for $3 \mathrm{~h}$ at $139,000 \times g$ at $5^{\circ} \mathrm{C}$. A syringe with an attached bent needle was used to collect the banded translucent white band that appeared 9 to $10 \mathrm{~mm}$ above the bottom of the tube. The collected virus was brought to $5 \mathrm{ml}$ with GB and pelleted by centrifugation for $1 \mathrm{~h}$ at $85,000 \times g$ at $5^{\circ} \mathrm{C}$. Purified virus then was used for antiserum preparation.

Antiserum was produced in a New Zealand white rabbit by Affinity BioReagents (Golden, CO). The rabbit was injected on days $1,22,36$, and 50 with $500 \mu \mathrm{g}$ of purified virus each time. Blood was collected on days 46, 60, and 64. Antiserum raised to TriMV was collected on day 60 (bleed 2) and used as a whole serum at a 1:4,000 ( $\mathrm{vol} / \mathrm{vol}$ ) dilution prepared from a solution of $1 \mathrm{mg}$ of protein per milliliter of stock. Antiserum to other viruses was prepared or obtained as described previously, and working dilutions were made from stocks adjusted to protein at $1 \mathrm{mg} / \mathrm{ml}$, at follows: WSMV (1:1,000 vol/vol; 29), HPV (1:50,000 vol/vol; 37), WASMV (1:600 vol/vol; 34), AgMV (1:1,000 vol/vol; 29), WYHV (1:800 vol/vol; 38), MDMV $(1: 1,000 \mathrm{vol} / \mathrm{vol} ; 31), \quad$ SCMV-MDB $(1: 1,000 \mathrm{vol} / \mathrm{vol} ; 33)$, HPV $(1: 1,000 ; 25)$ (provided by R. Louie, United Stated Department of Agriculture-Agricultural Research Service [USDA-ARS], Wooster, OH), JGMV (1:1,000 vol/vol; 32), SrMV (1:1,000 vol/vol; provided by K. Scholtoff, Texas A\&M, University, College Station), BMV (1:4,000 vol/vol; 45), and SCSMV (1:400 vol/vol; provided by R. French, USDA-ARS, University of Nebraska, Lincoln).

Indirect ELISA. The indirect ELISA was performed as described previously (42). Leaf tissue was ground in a $1.5-\mathrm{ml}$ microcentrifuge tube using a wooden ap- plicator stick (catalog no. 19-086-333; Fisher Scientific, Denver) at 1:30 (wt/vol) in $0.05 \mathrm{M}$ carbonate buffer, $\mathrm{pH} 9.6$ (8). Extracts $(200 \mu \mathrm{l})$ were placed in wells of ELISA plates (Immulon 1, catalog no. 1424578; Fisher Scientific) for $1 \mathrm{~h}$ at $37^{\circ} \mathrm{C}$. Following rinsing, the wells were incubated for $1 \mathrm{~h}$ at $37^{\circ} \mathrm{C}$ with the appropriate antivirus antibody in dilution buffer (8). The plates then were rinsed and blocked for $1 \mathrm{~h}$ in blocking buffer $(5 \%$ nonfat dry milk, $0.01 \%$ antifoam $\mathrm{A}$, and $0.02 \%$ sodium azide, in phosphatebuffered saline, $\mathrm{pH} 7.4$ ) at $37^{\circ} \mathrm{C}$. Then, 200 $\mu \mathrm{l}$ of anti-rabbit antibody/alkaline phosphatase conjugate (Southern Biotechnology Associates, Birmingham, AL) in dilution buffer $(1: 3,000 \mathrm{vol} / \mathrm{vol})$ was added to each well. The plates were held at $37^{\circ} \mathrm{C}$ for $1 \mathrm{~h}$. The plates then were rinsed, and 200 $\mu \mathrm{l}$ of p-nitrophenyl phosphate substrate at $0.714 \mathrm{mg} / \mathrm{ml}$, in substrate buffer (8), was added to each well. The plates then were held at 20 to $22^{\circ} \mathrm{C}$ for $30 \mathrm{~min}$. Absorbance was measured at $405 \mathrm{~nm}$ using a Titertek Multiscan plate reader (Flow Laboratories, Inc., McLean, VA). Absorbance values were arbitrarily considered positive if they were twice those of the equivalent mockinoculated control.

Electron microscopy. Leaf dip technique $(5,6)$ was used to prepare purified virus for viewing under an electron microscope (FEI CM100 Transmission Electron Microscope). Formvar-coated 150-mesh copper grids (catalog no. FF150-Cu; EMS, Hatfield, PA) were placed onto a 50- $\mu$ l suspension of purified virus for $20 \mathrm{~s}$. Immediately following, the grid was negatively stained on a $20-\mu$ l droplet of $2 \%$ uranyl acetate for $1 \mathrm{~min}$. Virion dimensions were estimated using the microscope software.

SDS-PAGE and Western blotting. Proteins from infected or mock-inoculated wheat were extracted and purified following the procedure of Lane (22) as described previously (36). The extracts were prepared by grinding $1.0 \mathrm{~g}$ of wheat leaf tissue $(1: 5 \mathrm{wt} / \mathrm{vol})$ with a mortar in a pestle in GB. This extract was filtered through cheesecloth and centrifuged for $20 \mathrm{~min}$ at $5,900 \times g$. The resulting supernatant was combined with $2 \mathrm{ml}$ of $33 \%$ Triton X-100 and centrifuged through a $10-\mathrm{cm}$ layer of $0.988 \mathrm{M}$ sucrose in GB for $2 \mathrm{~h}$ at $85,000 \times$ $g$. The supernatant was discarded and the pellet resuspended in $200 \mu \mathrm{l}$ of SDS treatment buffer $(0.125 \mathrm{M}$ Tris-Cl, ph $6.8 ; 4 \%$ SDS; $20 \%$ glycerol; and $10 \%$ 2mercaptoethanol), heated for $4 \mathrm{~min}$ at $100^{\circ} \mathrm{C}$, reduced, and alkylated (21). Then, $20 \mu \mathrm{l}$ was loaded into a well of a $10 \%$ acrylamide gel and molecular weight markers (Sigma Markers M3913; Milwaukee, WI) were loaded into other wells. Electrophoresis was conducted using the procedure of Laemmli (20). The gels were stained with Coomassie Blue R-250 (35). All electrophoretic analyses were repeated 
three times, with extracts from different part extracts from mock-inoculated wheat serving as controls for analyses.

During Western blot analyses, proteins from infected and mock-inoculated wheat tissue were extracted and separated on SDS-PAGE as described above. Three plants used for each analysis and counter-

acrylamide gels were loaded identically, one for Coomassie Blue R-250 staining and the other two for the Western blotting analysis, with prestained molecular weight markers (Bio-Rad 161-0305). Once the proteins were separated by SDS-PAGE, they were transferred onto wetted nitrocellulose (NitroCell $0.45 \mu \mathrm{m}$; GE Health

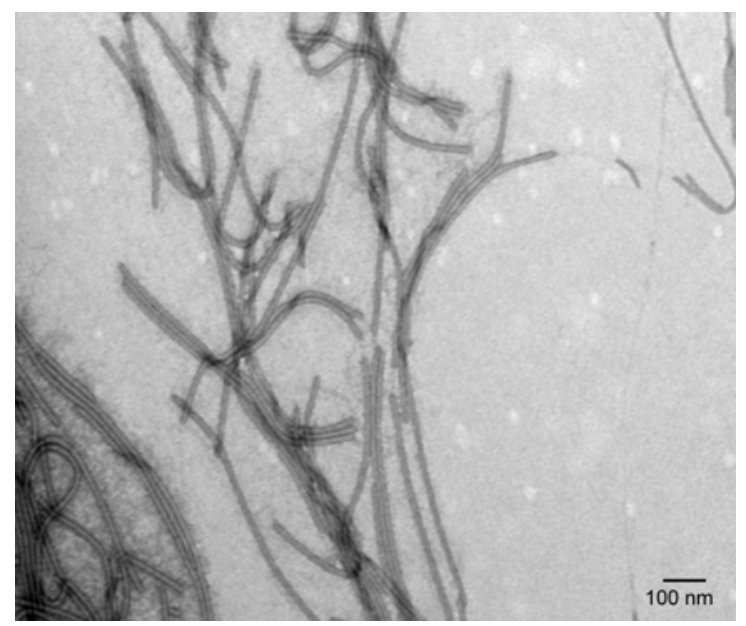

Fig. 1. Ultrastructural analysis of virions of Triticum mosaic virus (TriMV). A transmission electron micrograph of CsCl-purified TriMV negatively stained with uranyl acetate. The bar represents a length of $100 \mathrm{~nm}$.

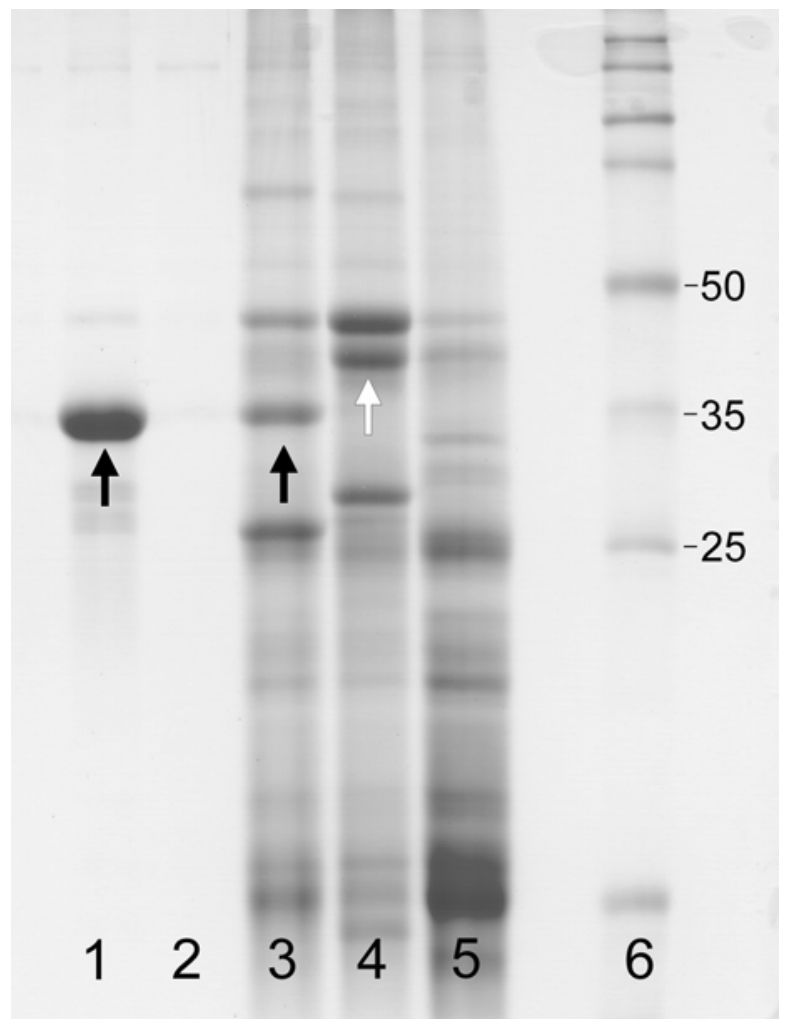

Fig. 2. Protein concentrated from 'Tomahawk' wheat (infected or healthy) and separated by sodium dodecyl sulfate polyacrylamide gel electrophoresis. Lane 1, CsCl-purified Triticum mosaic virus (TriMV); lane 2, CsCl-purified healthy wheat with the sample taken from the same position on a corresponding gradient as for the TriMV sample in lane 1; lane 3, resuspended pellet from TriMVinfected leaf tissue, having passed through the $20 \%$ sucrose purification step; lane 4 , resuspended pellet from leaf tissue infected by the Sidney 81 isolate of Wheat streak mosaic virus (WSMV) treated as described for TriMV in lane 3; lane 5, resuspended pellet from healthy leaf tissue treated as described for TriMV in lane 3; and lane 6, molecular weight markers. The vertical arrows in lanes 1 and 3 mark the location of the $35-\mathrm{kDa}$ protein unique to TriMV, $\mathrm{CsCl}$ or sucrose purified, respectively, and the vertical white arrow in lane 4 marks the location of the WSMV coat protein.
Care, Piscataway, NJ) at $100 \mathrm{~V}$ in a TE-52 Transphor electrophoresis cell (GE Health Care) using a transfer buffer $(39 \mathrm{mM}$ glycine; $40 \mathrm{mM}$ Tris-Cl, pH 8.3; $0.037 \%$ SDS; and 20\% vol/vol methanol) (55). Western blotting was conducted using alkaline phosphatase-antirabbit goat antibody conjugate $(1: 3,000$ dilution; catalog no. 4050-04; Fisher Scientific) (7). Membranes were developed for 20 to $30 \mathrm{~min}$. Antibodies to TriMV and WSMV were used at a 1:4,000 (vol/vol) and 1:2,000 (vol/vol) dilution, respectively.

Time-of-flight mass spectrometry. Proteins in gel slices first were subjected in situ to a full tryptic digest overnight. In addition, one sample was digested fully using Asp-N. To obtain larger peptides that would arise from missed cleavages, a second set of samples was partially digested with trypsin for $4 \mathrm{~h}$. In preliminary examinations, each digest was measured directly (without prior reversed-phase high-performance liquid chromatography [RP-HPLIC] fractionation) in a matrix-assisted laser desorption ionization (MALDI)-Qq time-of-flight (TOF) instrument (24). For more detailed analyses, the proteolyzed fragments were separated into 40 1-min fractions by RP-HPLC, and deposited onto a MALDI target by a robot previously constructed in the Manitoba laboratory (18). The mass-to-charge $(\mathrm{m} / \mathrm{z})$ spectrum for each spot then was acquired in the same TOF mass spectrometry (MS) instrument.

Candidate proteins initially were identified using SMART, a software tool for retention time-based peptide mass fingerprinting that was developed at the University of Manitoba (19). No significant matches were identified in the database at this stage, thus confronting requiring de novo sequencing (54). The only proteins clearly identified were contaminants such as keratins, which were removed in silico by software. The 30 most intense remaining peptide peaks were chosen for further analyses by tandem MS (MS/MS) measurements. In addition, more detailed measurements were made on a tryptic digest with a 1:1 mixture of $0^{18}$-labeled water with unlabeled water (47) to distinguish peptide ions that contain the $\mathrm{C}$-terminus. The results of the de novo sequencing were submitted to MS-BLAST (48) for homology-based protein sequence identification.

Cloning and sequencing of the coat protein. The Qiagen Plant RNAesy kit (Qiagen) was used to isolate viral RNA from purified virus particles. cDNA synthesis reactions $(50 \mu \mathrm{l})$ consisted of $100 \mathrm{ng}$ of viral RNA as a template, $1 \mu \mathrm{l}$ of $1 \mathrm{mM}$ dNTPs, 50 pmoles of oligo $\mathrm{d}(\mathrm{t})_{18}$ primer, 4 $\mu \mathrm{l}$ of $5 \times$ first-strand buffer, $2 \mu \mathrm{l}$ of $0.1 \mathrm{M}$ dithiothreitol, and 200 units of Superscript II RT (Invitrogen, Carlsbad, CA), all according to the manufacturer's protocol. Reactions were incubated at $42^{\circ} \mathrm{C}$ for $2 \mathrm{~h}$. Nucleotide sequences for the coat protein (CP) were amplified using $1 / 10$ of the 
reverse transcription reaction. Degenerate polymerase chain reaction (PCR) primers for the $\mathrm{CP}$ were designed from reverse translations of the amino acid sequences determined by TOFMS analyses. Forward primers were CP1 5'-ATG(M)TGG(W) TAY(Y)CAN(T)CCN(P)CCN(P)GA-3' and CP3 5'-TTY(F)TAY(Y)CCN(P)TGY(C) TGY(C)YTN(L)GAY(D)TT-3'. The initial reverse primer was oligo $\mathrm{d}(\mathrm{T})_{18}$. A secondary reverse primer, CP1R 5'-CTCTAA CAAGCTCTGTGAGC-3', was designed from cloned sequences and used with random octamers to obtain the nucleotide sequence upstream of the protease cleavage site.

The PCR reactions included 5 pmoles of each primer, $1 \times$ final concentration Taq polymerase buffer (Sigma-Aldrich, St. Louis), $10 \mathrm{mM}$ dNTPs, and 0.25 units of Taq polymerase (Sigma-Aldrich). Products were amplified using an MJ Research thermocycler with 35 cycles of $92^{\circ} \mathrm{C}$ denaturation for $1 \mathrm{~min}, 55^{\circ} \mathrm{C}$ annealing for 2 min, and extension of $72^{\circ} \mathrm{C}$ for $2 \mathrm{~min}$. PCR fragments were cloned into the pCR2.1 TA-cloning vector (Invitrogen). The plasmids were purified using Qiagen Spin Miniprep Kit and sequenced using BigDye terminator chemistry (Applied Biosystems, Foster City, CA) at the Kansas State University Sequencing facility on an ABI 3730s DNA Analyzer. DNA sequences were analyzed and protein predictions made using MacVector (ver. 9.0; MacVector Inc., Cary, NC). Contiguous sequence was assembled using MacVector Assembler (ver. 1.0).

\section{RESULTS}

Virus source. Extracts from the wheat cv. KS06HW79, the source of the U06-123 isolate of TriMV, failed to react in ELISA against WSMV, HPV, AgMV, FoMV, and WASMV antibodies. Analysis by SDSPAGE showed that these extracts contained a unique protein of approximately $35 \mathrm{kDa}$ (data not shown). The infectious agent in KS06HW79 wheat first was transmitted mechanically to Tomahawk wheat on 26 April 2006. Sap extracts from symptomatic Tomahawk wheat plants that subsequently developed symptoms also contained the 35-kDa protein (data not shown) and failed to react against WSMV antibodies in ELISA. The extracts made after the fifth transfer, following four cycles of mechanical transmission of the U06123 isolate to Tomahawk, still contained the $35-\mathrm{kDa}$ protein (data not shown) and they tested negative in ELISA for WSMV. Thus, the same pathogenic agent was present in these fifth-cycle plants infected by the U06-123 isolate as would be expected if Koch's postulates were fulfilled. These infected plants were used for virus purification, electron microscopy, and production of specific antiserum.

Virus purification and electron microscopy. An optically dense band was evident after $\mathrm{CsCl}$ centrifugation of extracts prepared from systemically infected, symptomatic wheat leaves (data not shown). This band was always present 9 to $10 \mathrm{~mm}$ from the bottom of the centrifuge tube and was not present in extracts prepared from mock-inoculated wheat. Aliquots taken from such optically dense bands contained flexuous, virus-like particles (Fig. 1). However, in preparations from two separate purifications, the viruslike particles were aggregated either side by side or end to end, making measurements difficult. In both preparations, some short particles were present as well. Twenty particles that appeared as discrete virions were $15 \mathrm{~nm}$ wide and ranged in length from 550 to $909 \mathrm{~nm}$, with a modal length of $800 \mathrm{~nm}$.

SDS-PAGE analyses. A unique protein of approximately $35 \mathrm{kDa}$ was observed when aliquots of the CsCl-purified material were analyzed by SDS-PAGE (Fig. 2). The band was observed in wheat plants that had been through several cycles of mechanical infection by the U06-123 isolate, as well as from extracts of symptomatic wheat plants infected by presumed isolates of TriMV obtained from other locations (data not shown). When the aliquot from the resuspended pellet from the $20 \%$ sucrose purification step was analyzed for wheat infected by WSMV, only the band associated with the CP of WSMV was observed. This was in contrast to similar tissue infected by TriMV where only the $35-\mathrm{kDa}$ protein was observed. Thus, these results again fulfilled Koch's postu-

Table 1. Enzyme-linked immunosorbent assay values from different dilutions of antiserum raised against the U06-123 isolate of Triticum mosaic virus (TriMV) when used to analyze 1:30 wt/vol extracts of healthy or TriMV-infected 'Tomahawk' wheat ${ }^{\mathrm{z}}$

\begin{tabular}{lccccccccc}
\hline & \multicolumn{7}{c}{ Reciprocal of antiserum dilution } \\
\cline { 2 - 9 } Sample & $\mathbf{1 0 0}$ & $\mathbf{2 0 0}$ & $\mathbf{4 0 0}$ & $\mathbf{8 0 0}$ & $\mathbf{1 , 6 0 0}$ & $\mathbf{3 , 2 0 0}$ & $\mathbf{6 , 4 0 0}$ \\
\hline U06-123 & 1.684 & 1.663 & 1.400 & 0.959 & 0.686 & 0.419 & 0.218 \\
Healthy wheat & 0.075 & 0.048 & 0.029 & 0.017 & 0.018 & 0.010 & 0.010 & 0.116 \\
\hline
\end{tabular}

${ }^{\mathrm{z}}$ Bleed number 2 (60 days). Values presented are representative of two analyses.

Table 2. Enzyme-linked immunosorbent assay (ELISA) values using antisera raised to different viruses to analyze extracts of wheat or sorghum infected by the homologous or heterologous virus ${ }^{\mathrm{y}}$

\begin{tabular}{lcccccccccc}
\hline & \multicolumn{10}{c}{ Antisera prepared to the different viruses $^{\mathbf{z}}$} \\
\cline { 2 - 10 } Virus or control & TriMV & MDMV & SCMV & JGMV & SrMV & AgMV & BMV & WSMV & HPV & FoMV \\
\hline TriMV U06-123 & $\mathbf{0 . 4 4 6}$ & 0.017 & 0.023 & 0.070 & 0.027 & 0.024 & 0.028 & 0.035 & 0.033 & 0.027 \\
MDMV-AKS & 0.002 & $\mathbf{0 . 1 3 3}$ & 0.038 & 0.195 & 0.011 & 0.045 & 0.008 & 0.056 & 0.094 & 0.040 \\
SCMV-MDBKS & 0.001 & 0.001 & $\mathbf{0 . 2 2 0}$ & 0.094 & 0.006 & 0.001 & 0.001 & 0.001 & 0.001 & 0.001 \\
JGMV-KS & 0.001 & 0.001 & 0.005 & $\mathbf{1 . 1 5 9}$ & 0.007 & 0.069 & 0.001 & 0.001 & 0.001 & 0.001 \\
SrMV-PV323 & 0.003 & 0.005 & 0.030 & 0.119 & $\mathbf{0 . 4 4 2}$ & 0.020 & 0.012 & 0.041 & 0.083 & 0.011 \\
AMV-PV75 & 0.018 & 0.007 & 0.022 & 0.315 & 0.016 & $\mathbf{1 . 2 6 3}$ & 0.001 & 0.001 & 0.024 & 0.001 \\
BMV-PV47 & 0.022 & 0.017 & 0.024 & 0.069 & 0.026 & 0.034 & $\mathbf{1 . 3 9 9}$ & 0.108 & 0.049 & 0.055 \\
WSMV-Sid81 & 0.028 & 0.011 & 0.020 & 0.066 & 0.019 & 0.042 & 0.062 & $\mathbf{0 . 5 6 1}$ & 0.056 & 0.005 \\
HPV-WO & 0.034 & 0.007 & 0.035 & 0.115 & 0.020 & 0.067 & 0.011 & 0.081 & $\mathbf{0 . 7 7 9}$ & 0.025 \\
FoMV-H93 & 0.001 & 0.001 & 0.001 & 0.030 & 0.001 & 0.097 & 0.008 & 0.072 & 0.074 & $\mathbf{0 . 4 0 3}$ \\
Healthy wheat & 0.020 & 0.020 & 0.020 & 0.038 & 0.020 & 0.020 & 0.020 & 0.020 & 0.020 & 0.020 \\
Healthy sorghum & 0.007 & 0.010 & 0.008 & 0.063 & 0.020 & 0.021 & 0.008 & 0.060 & 0.061 & 0.018 \\
\hline
\end{tabular}

${ }^{\mathrm{y}}$ TriMV = Triticum mosaic virus, MDMV = Maize dwarf mosaic virus, SCMV = Sugarcane mosaic virus-MDB, JGMV = Johnsongrass mosaic virus, SrMV = Sorghum mosaic virus, AgMV = Agropyron mosaic virus, $\mathrm{BMV}=$ Brome mosaic virus, $\mathrm{WSMV}=$ Wheat streak mosaic virus, $\mathrm{HPV}=\mathrm{High}$ Plains virus, and FoMV = Foxtail mosaic virus. The KS following certain isolates identifies the viruses as Kansas sources. The data presented are representative of two experiments.

${ }^{\mathrm{z}}$ Antisera dilutions used are given in Materials and Methods. Bold numbers represent the homologous reaction of antiserum and virus and numbers in italics indicate reactions considered positive in ELISA based upon the arbitrary declaration that values meeting or exceeding twice that of the appropriate healthy control. 


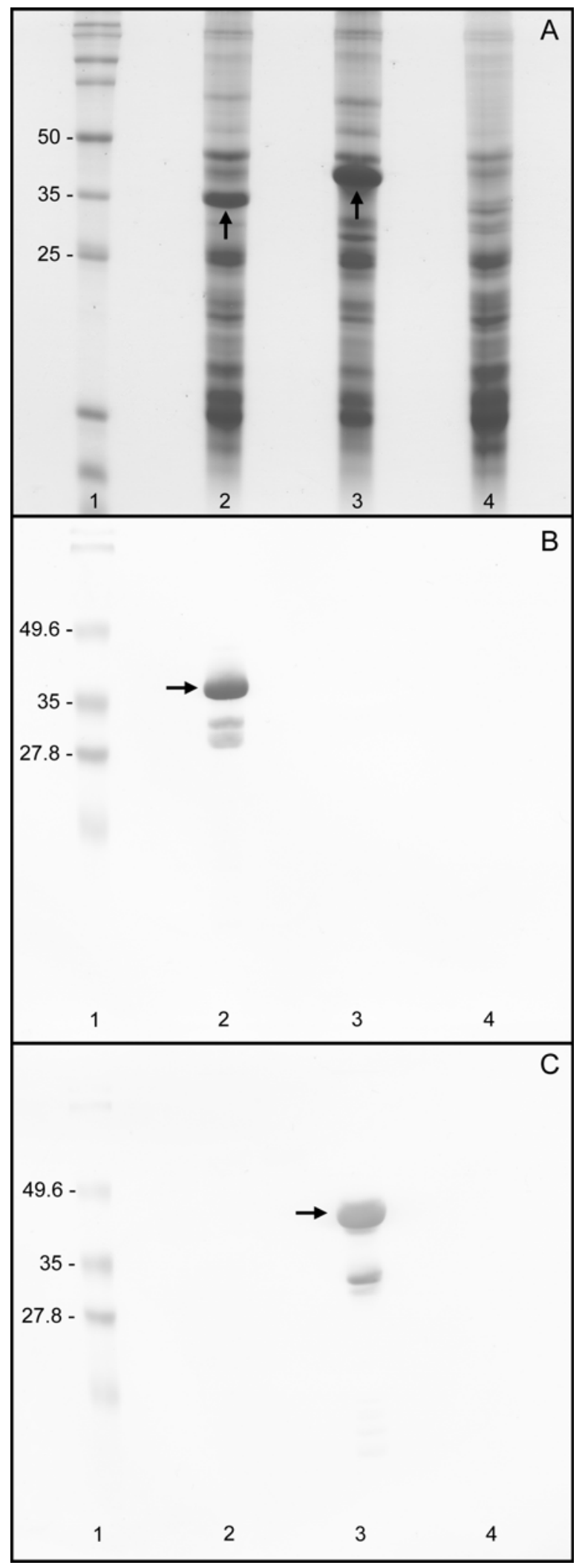

Fig. 3. Analysis of proteins of wheat infected with Triticum mosaic virus (TriMV) and Wheat streak mosaic virus (WSMV). A, Protein concentrated from 'Tomahawk' wheat (infected or healthy), separated by sodium dodecyl sulfate polyacrylamide gel electrophoresis (SDS-PAGE), and stained with Coomassie blue; B, blot of SDS-PAGE gel probed with antibodies made to purified virions of the U06-123 isolate of TriMV; and C, blot of SDS-PAGE gel probed with antibodies made to purified virions of the Sidney 81 isolate of WSMV. A, Lane 1, molecular weight markers; lane 2, extract from TriMV-infected wheat; lane 3 , extract from WSMV-infected wheat; and lane 4, extract from healthy Tomahawk wheat. In lane 2, the arrow marks the location of the 35-kDa protein associated with TriMV; and in lane 3, the arrow marks the location of the capsid protein of WSMV. B and $\mathbf{C}$, Samples are the same as described for A, except that lane 1 contains prestained mass markers. Arrows mark the location of the proteins from TriMV-infected wheat reacting to $\mathbf{B}$, antibodies made to purified TriMV, and $\mathbf{C}$, antibodies made to the purified WSMV. lates in identifying the agent infecting the wheat and causing the mosaic symptoms.

Antiserum specificity and Western blotting. Titration in ELISA of the antiserum from bleed 2 showed that it reacted robustly against extracts of Tomahawk wheat systemically infected by the U06123 isolate of TriMV (Table 1). The ELISA values for extracts from mockinoculated plants ranged from 0.075 at the 1:100 dilution to 0.010 for the 3,200 to 12,800 dilutions. In ELISA tests against an array of other viruses known to infect wheat, the TriMV antiserum reacted only to extracts from tissue infected with the U06-123 isolate (TriMV) and not to extracts of mock-inoculated wheat or wheat infected with the other viruses (Table 2). In these tests, every virus reacted with its homologous antiserum, indicating that the sample tissues analyzed were infected with the appropriate virus.

Using SDS-PAGE (Fig. 3A), the unique capsid proteins of both TriMV and WSMV were observed in minipurified extracts made from wheat samples. After protein transfer to solid membranes, probes of anti-TriMV serum reacted specifically to the $35-\mathrm{kDa}$ protein and to two lower molecular weight proteins in extracts of wheat infected by TriMV but not to extracts of mock-inoculated plant tissue (Fig. 3B). Conversely, when the membrane was probed with anti-WSMV serum, only the major WSMV capsid protein and two lower molecular weight proteins reacted positively (Fig. 3C).

Field sampling of wheat and barley. ELISA analysis of frozen wheat samples from six counties in Kansas showed that TriMV was present in suspect wheat from all locations (Table 3). Samples from Osborne and Thomas Counties were singly infected by TriMV. Samples from Pawnee were double infected by TriMV and WSMV. However, plants from Ellis, Ford, and Ness Counties tested positive for both single infection by TriMV and double infection by both TriMV and WSMV. To evaluate host range, eight symptomatic barley plants from test plots at the KSUARCH were analyzed by ELISA. Data indicated that some were infected singly by either TriMV or WSMV and others were doubly infected by TriMV and WSMV (Table 4). Barley lines NB03435, NB99875, VA04H-53, and VA03H-61 tested positive for infection by TriMV. Single infection by WSMV occurred in a barley plant in lines VA03H-61 and NB0442 and double infection occurred for one plant each in the barley lines VA01H125 and NB03435.

Plant dry weight analysis. TriMV induced systemic symptoms within 14 days in WSMV-resistant RonL. Although symptoms appeared on plants maintained in the $18^{\circ} \mathrm{C}$ regime, the symptoms were clearly more severe on plants held at $24^{\circ} \mathrm{C}$ (Table 5 ). The effects of such infection were re- 
flected in significantly reduced dry weight of symptomatic tissue compared with mock-inoculated controls. By contrast, KS96HW10-3, whose WSMV resistance is derived from a different source than RonL, failed to develop TriMV symptoms in the $18^{\circ} \mathrm{C}$ regime but developed a systemic faint mosaic by $14 \mathrm{DPI}$ when held at $24^{\circ} \mathrm{C}$. KS96HW10-3 also did not show any significant reduction in dry weight at either temperature compared with mockinoculated healthy controls.

Sequence of the 35-kDa protein. The tryptic digests yielded 28 peptides after HPLC separation which then were sequenced de novo (Table 6). However, after similar HPLC separations, the Asp-N digest yielded only a subset of the expected complement of proteolytic fragments and some overlapped with the tryptic fragments. Together, longer sequence strings could be generated but the TriMV CP amino acid sequence obtained by TOFMS mass measurements was still incomplete, with the amino acids at locations 100 to 133,150 to 169,183 to 186 , and 195 to 197 not determined (Fig. 4). In addition, ambiguities in the initial TOMFS data are presented in Table 6 . Nevertheless, this set of peptide sequences was sufficient to show that the parent $35-\mathrm{kDa}$ protein was related to the 283-amino-acid (aa) CP of Sugarcane streak mosaic virus (SCSMV) (Fig. 4), (SCSMVA80PX)/AY193783) (12), because it was the only significant homology detected by the extensive MSBLAST search in that sequence database. This discovery was a crucial step that allowed for design of primers for the subsequent nucleotide sequence determination.

The partial amino acid sequence of the TriMV 35-kDa protein, as determined by TOFMS, was used to design degenerate primers to synthesize cDNA from the RNA isolated from purified virus particles. Five individual clones were sequenced from the reverse-transcription (RT)-PCR reaction, using primers $\mathrm{CP} 1$ and oligo $\mathrm{d}(\mathrm{T})_{18}$. The insert was 681 nucleotides (nt) long, (not including the poly A tail). The insert contained a computer-predicted open reading frame in the +2 frame with a stop codon at position 493 to 681 . The 163 -aa computertranslated protein was found to contain a conserved domain found in potyviral $\mathrm{CP}$ (pfam00767,Poty_coat, potyvirus CP). Based on alignments with polyprotein of SCSMV (CAA76842) (11) and other potyvirus $\mathrm{CP}$ sequences, it appeared that the putative $\mathrm{CP}$ sequence was not complete. To go further upstream, a reverse specific primer, $\mathrm{CP} 1 \mathrm{R}$, was designed $53 \mathrm{nt}$ from the start of the sequence. After PCR with random octamer primers, the major resulting cDNA band was isolated, cloned, and sequenced. After assembly of the nucleotide sequences, the translated protein was compared with the TOFMS data and aligned with SCSMV (Fig. 4). The CP was pre- dicted to be 293 aa long based on matching amino acids at the amino terminus of the TOFMS data and the presence of a putative NIa-protease cleavage site of VFHS/G (1) in the predicted protein. Based on this data, the coding length of the CP was 882 nt.

BLAST alignment with the protein database confirmed the similarity between the TriMV CP amino acid sequence and the CP of SCSMV. Although the TriMV sequence was most similar to SCSMV, the $50.2 \%$ difference in their amino acid sequences indicated that the two viruses were not closely related. The TriMV protein had 293 aa compared with 283 aa for SCSMV. A molecular weight of $32 \mathrm{kDa}$ was calculated for the TriMV CP using the deduced amino acid sequence; $3 \mathrm{kDa}$ different from the $35-\mathrm{kDa}$ value determined by SDS-PAGE. Two differences were observed between the predicted TriMV and the TOFMS-derived amino acid sequence. At position 39, an aspartic acid residue is present instead of asparagine and there is an addition of a glutamic acid residue at the N-terminus (Fig. 4; Table 6).

\section{DISCUSSION}

When WSMV-like symptoms in April 2006 appeared on KS06HW79, a wheat line with temperature-sensitive resistance to WSMV (D. L. Seifers, unpublished), two possibilities were considered. It was a possibility that either warmer temperatures had broken the resistance and enabled

Table 3. Kansas counties, number of wheat plants analyzed by enzyme-linked immunosorbent assay (ELISA), and the number wheat plants infected by Triticum mosaic virus (TriMV) or doubly infected with TriMV and Wheat streak mosaic virus (WSMV) in $2006^{\mathrm{z}}$

\begin{tabular}{lccc}
\hline & & \multicolumn{2}{c}{ Infecting virus or viruses } \\
\cline { 3 - 4 } Kansas county & No. of plants analyzed & TriMV & TriMV and WSMV \\
\hline Ellis & 29 & 12 & 17 \\
Ford & 2 & 1 & 1 \\
Ness & 5 & 1 & 4 \\
Osborne & 2 & 2 & 0 \\
Pawnee & 2 & 0 & 2 \\
Thomas & 1 & 1 & 0
\end{tabular}

${ }^{\mathrm{z}}$ Wheat samples were frozen at $-80^{\circ} \mathrm{C}$ and then analyzed $(1: 30 \mathrm{w} / \mathrm{v}$ dilution) when antiserum was prepared to TriMV. ELISA values were considered positive for infection by TriMV and WSMV when they were twice that of the healthy wheat control.

Table 4. Enzyme-linked immunosorbent assay (ELISA) values determined for symptomatic barley plants sampled at the Kansas State University Agricultural Research Center-Hays during 2006 using antiserum made to Triticum mosaic virus (TriMV) and Wheat streak mosaic virus (WSMV)z

\begin{tabular}{lcccc}
\hline & \multicolumn{2}{c}{ ELISA values from plants considered singly or doubly infected } \\
\cline { 2 - 3 } Line & \multicolumn{2}{c}{ Singly infected plants } & & \multicolumn{2}{c}{ Doubly infected plants } \\
\cline { 2 - 3 } \cline { 2 - 3 } TriMV & WSMV & & TriMV & WSMV \\
\hline NB03435 & 0.424 & 0.033 & - & - \\
NB99875 & 0.309 & 0.039 & - & - \\
VA01H-125 & - & - & 0.574 & 0.489 \\
VA04H-53 & 0.609 & 0.034 & - & - \\
VA03H-61 & 0.001 & 0.269 & - & - \\
VA03H-61 & 0.386 & 0.033 & - & - \\
NB03435 & - & - & 0.197 & 0.235 \\
NB04427 & 0.001 & 0.348 & - & - \\
TriMV & 0.311 & 0.028 & 0.311 & 0.028 \\
WSMV & 0.001 & 0.186 & 0.001 & 0.186 \\
Healthy barley & 0.010 & 0.041 & 0.010 & 0.041 \\
\hline
\end{tabular}

z Samples were frozen at $-80^{\circ} \mathrm{C}$ and then analyzed $(1: 30 \mathrm{w} / \mathrm{v}$ dilution) when antiserum was available for TriMV; - = no ELISA value because plant was not either singly or doubly infected as appropriate for each sample.

Table 5. Average dry weight (grams) and symptoms expressed by wheat either healthy (H) or inoculated (I) with Triticum mosaic virus when held at different temperatures for 28 days ${ }^{\mathrm{z}}$

\begin{tabular}{lccccc}
\hline & \multicolumn{2}{c}{$\mathbf{1 8}^{\circ} \mathbf{C}$} & & \multicolumn{2}{c}{$\mathbf{2 4}^{\circ} \mathbf{C}$} \\
\cline { 2 - 3 } \cline { 5 - 6 } Wheat & Symptoms & Dry weight & & Symptoms & Dry weight \\
\hline KS96HW10-3 I & NS & $0.628 \mathrm{C}$ & & FM & $0.570 \mathrm{C}$ \\
KS96HW10-3 H & NS & $0.632 \mathrm{C}$ & & NS & $0.577 \mathrm{C}$ \\
RonL I & MM & $0.781 \mathrm{~B}$ & & SM & $0.660 \mathrm{~B}$ \\
RonL H & NS & $0.912 \mathrm{~A}$ & & NS & $0.814 \mathrm{~A}$ \\
\hline
\end{tabular}

${ }^{\mathrm{z}}$ Averages are values from three experiments. $\mathrm{NS}=$ no symptoms, $\mathrm{FM}=$ faint mosaic, $\mathrm{MM}=$ moderate mosaic, and SM = severe mosaic. Treatment means not followed by the same letter differ according to the least significant difference test at $P=0.05$. 
systemic WSMV infection $(41,42)$, or that the symptoms had been induced by infection with recently identified HPV variants that do not react in a robust manner to HPV antiserum (29). However, ELISA of sap extracts from the symptomatic plants detected neither WSMV nor HPV antigens. This eliminated WSMV but the possibility remained that an HPV variant was responsible but failed to react to HPV antiserum (30). However, this latter hypothesis was substantially weakened by the finding from SDS-PAGE analysis of the unique $35-\mathrm{kDa}$ protein that was $3 \mathrm{kDa}$ larger than those associated with HPV and HPV variants (30,37).

We demonstrated that an extract of the original infected plant (KS06HW79) could infect wheat by mechanical (finger-rub) inoculation, and this first transmission of an infectious agent became the source of the isolate designated U06-123. Transmis- sion by rub inoculation immediately eliminated WYHV and WASMV as candidate causal agents, because these viruses are not mechanically transmissible $(34,38)$. The inoculated test plants developed mosaic symptoms resembling those on the source plant, and the sap extracts of these plants failed to react against anti-WSMV serum in ELISA but contained the unique band migrating at approximately $35 \mathrm{kDa}$ in SDS-PAGE, indicating that the U06-123 isolate was the cause of the disease observed in the field. These extracts also failed to react with anti-AgMV and antiBMV sera. Both viruses are mechanically transmissible and have been found to infect wheat in Kansas $(29,45)$.

The protocol used previously to purify AgMV (29), Zea mosaic virus (43), and WYHV (38) yielded virus-like particles from wheat systemically infected by TriMV (Fig. 1). The estimated modal length for TriMV of $800 \mathrm{~nm}$ is based on a small number of measurements and should be interpreted cautiously. To date, we have not pursued efforts to modify the protocol so that it might yield nonaggregated virus particles because we have given priority to other areas of research concerning TriMV. Using this purification technique, we were able to raise anti-TriMV serum that did not cross-react in Western blots to WSMV or to protein extracts from healthy plants. The antiserum did, however, react specifically with the $35-\mathrm{kDa}$ protein that was always observed in successive transmission of TriMV (Figs. 2 and 3A-C). Because these proteins were not seen in blots of extracts from mock-inoculated wheat, we believe that the two additional minor bands migrating slightly faster than the $35-\mathrm{kDa}$ protein are, in fact, breakdown products from the TriMV CP. This is similar to previous work, in which anti-WSMV sera

Table 6. Preliminary determination by time-of-flight mass spectrometry of de novo sequences of tryptic and asparagine-N peptides with calculated retention times of high pressure liquid chromatography fractions ${ }^{\mathrm{n}}$

\begin{tabular}{|c|c|c|c|}
\hline Fraction $^{\circ}$ & RT-calcp & $\mathbf{M}+\mathbf{H}^{\mathbf{q}}$ & Originally proposed de novo sequence \\
\hline \multicolumn{4}{|l|}{ Trypsin } \\
\hline 7 & 6.74 & 674.349 & VSDTPR \\
\hline 8 & 7.53 & $1,081.467$ & RDDDANYGR \\
\hline 8 & 7.15 & 925.365 & DDDANYGR \\
\hline 9 & 10.4 & 815.441 & DQVLNAR $^{\mathrm{r}}$ \\
\hline 9 & 7.97 & 989.49 & EQDQSGVVK $^{\mathrm{s}}$ \\
\hline 10 & 10.46 & 814.45 & NQVLNAR $^{\mathrm{r}}$ \\
\hline 10 & 10.16 & $1,132.523$ & AGAGEEDTNLR $^{\mathrm{r}}$ \\
\hline 10 & 9.62 & $1,288.625$ & AGAGEEDTNLRR $^{\mathrm{r}}$ \\
\hline 12 & 11.93 & 721.382 & LSSWTK $^{\mathrm{r}, \mathrm{t}}$ \\
\hline 13 & 11.13 & 565.333 & FSLAK $^{\mathrm{r}}$ \\
\hline 13 & 12.18 & 849.483 & KLSSWTK $^{\mathrm{r}, \mathrm{t}}$ \\
\hline 14 & 13.4 & 850.437 & TLEQFGR $^{r}$ \\
\hline 14 & 19.58 & $1,370.721$ & YTFNLNATVVTK $\mathrm{K}^{\mathrm{r}, \mathrm{u}}$ \\
\hline 14 & 14.32 & 895.447 & VGQMFGTR $^{\mathrm{s}, \mathrm{v}}$ \\
\hline 12 & 14.32 & 911.428 & VGQMFGTR $(\mathrm{M}+16)^{\mathrm{s}, \mathrm{w}}$ \\
\hline 15 & 14.04 & 947.535 & SLVTLDTAK $^{\mathrm{r}}$ \\
\hline 15 & 17.62 & $1,130.7$ & KPLLPHNALK $^{\mathrm{r}}$ \\
\hline 15 & 17.43 & $1,286.629$ & RKPLLPHNALK $^{\mathrm{r}}$ \\
\hline 15 & 15.66 & $1,075.6$ & SLVTLDTAKK $^{\mathrm{r}}$ \\
\hline 16 & 15.52 & 934.484 & HFQLAYR $^{\mathrm{r}, \mathrm{s}}$ \\
\hline 17 & 20.43 & $1,212.627$ & YSTYLPPLMK ${ }^{\mathrm{r}, \mathrm{x}}$ \\
\hline 17 & 20.43 & $1,228.629$ & YSTYLPPLMK $(\mathrm{M}+16)^{\mathrm{r}, \mathrm{w}, \mathrm{x}}$ \\
\hline 17 & 17.84 & $1,510.74$ & LSTQACTLEQFGR $^{\mathrm{r}, \mathrm{s}}$ \\
\hline 20 & 24.98 & $2,148.065$ & CLDFVTVDQLSPQEIEVR ${ }^{\mathrm{n}, \mathrm{r}, \mathrm{y}}$ \\
\hline 23 & 27.02 & $2,585.217$ & MWYTPPDALLSTQACTLEQFGR ${ }^{\mathrm{n}, \mathrm{r}, \mathrm{t}}$ \\
\hline 23 & 27.02 & $2,601.204$ & MWYTPPDALLSTQACTLEQFGR $(\mathrm{M}+16)^{\mathrm{r}, \mathrm{t}, \mathrm{w}}$ \\
\hline \multicolumn{4}{|l|}{ ASP-N } \\
\hline 8 & 7.48 & $1,213.549$ & DPVNNPSDNNK $^{z}$ \\
\hline 9 & 7.06 & $1,182.522$ & DDDANYGRTR \\
\hline 10 & 6.91 & 592.261 & DYTPP \\
\hline 20 & 20.22 & $1,174.491$ & DVTFYPCCL $^{\mathrm{n}}$ \\
\hline \multicolumn{4}{|c|}{ Trypsin with 4-h digestion } \\
\hline 11 & 12.17 & $2,196.947$ & ETDPPNQAMDPVNNPSDNNK \\
\hline 27 & 30.09 & $3,402.642$ & KLMDVTFYPCCLCLDFVTVDQLSPQELEVR ${ }^{\mathrm{r}}$ \\
\hline
\end{tabular}

${ }^{\mathrm{n}}$ Peptides with a very strong homology with the target Sugarcane streak mosaic virus and were used to help construct the RNA sequence probes.

${ }^{\circ}$ The observed 1-min fraction in which peaks eluted.

$\mathrm{p}$ The predicted retention time (in minutes) for the reported peptide sequence, computed using SSRCalc for a 300-A pore size sorbent.

$\mathrm{q}$ The observed parent ion mass.

${ }^{\mathrm{r}} \mathrm{L}$ and I have the same mass; therefore, amino acid residues assigned as L could equally well be I.

${ }^{s} \mathrm{Q}$ could be GA. The mass difference is 0 .

${ }^{\mathrm{t}} \mathrm{W}$ could be $\mathrm{AD}$. The mass difference is approximately $15 \mathrm{mDa}$.

"YTF could be DAPQ. The mass difference is approximately $3 \mathrm{mDa}$.

${ }^{\mathrm{v}}$ Correctly assigned as the $\mathrm{C}$-terminal peptide from the absence of ${ }^{18} \mathrm{O}$ addition in the ${ }^{18} \mathrm{O}$ tryptic digest.

${ }^{\mathrm{w}}$ Oxidized $\mathrm{M}$.

${ }^{x}$ YS could be SY. The mass difference is 0 .

y LE could be QN. The mass difference is approximately $25 \mathrm{mDa}$.

${ }^{\mathrm{z}} \mathrm{N}$ could be GG. The mass difference is 0 . 
reacted to proteins that migrated just faster than the main $\mathrm{CP}$ that have been widely interpreted as breakdown products from the CP $(4,36)$. Serological analyses also indicated that TriMV is distinct from an array of other viruses that infect grasses (Table 2). These included MDMV, SCMV, JGMV, SrMV, WSMV, and AgMV, viruses in the family Potyviridae (56); BMV, a bromovirus (56); FoMV, a potexvirus (56); and HPV (affiliation not yet declared). The serological analyses again provided additional evidence for identifying the U06123 isolate as the cause of the disease in the field and further fulfilling Koch's postulates.

Therefore, we also tested the U06-123 isolate of TriMV against anti-SCSMV serum in ELISA (10) and determined that the anti-SCSMV antiserum did not react to the TriMV isolate. Although the SCSMV antiserum failed to react against the TriMV isolate, we cannot be confident of this negative result because we were unable to obtain a positive control to prove that the antiserum was reactive. Although the Uttar Pradesh isolate of SCSMV reacted with antiserum made to the SCSMV-AP isolate (27), it has been reported that the Andhra Pradesh isolate of SCSMV (SCMSV-AP) reacts positively to antiserum to Narcissus latent virus (11) but not to Sugarcane mosaic virus strains or potyvirus groupspecific antiserum (13). The evidence from electron microscopy of purified TriMV, while not definitive, also indicates that it is too distantly related to SCSMV to be considered a strain. With a modal length of $800 \mathrm{~nm}$, TriMV appears to be notably shorter than the 890 by $15 \mathrm{~nm}$ determined for SCSMV (12).

The failure of serological analyses to point to a clear candidate causal agent prompted the decision to submit the 35$\mathrm{kDa}$ protein that was consistently associated with the disease to analysis by TOFMS. This approach has been successful in the characterization of the agent of High Plains disease (44). The partial CP sequences determined by TOFMS and analyzed by MSBLAST pointed to a distant relationship of TriMV with the SCSMV CP but no significant homology to any other protein in the database. Although the TOFMS analysis identified regions of homology with SCSMV and, therefore, potential membership in the family Potyviridae, notable gaps and ambiguities remained in the $\mathrm{CP}$ amino acid sequence. By using primers reverse engineered from portions of the CP TOFMS amino acid sequence, the cloned CP confirmed the correct positioning of the peptides and completed gaps in the sequence and the correct start site of the CP. The sequence homology verifies that TriMV might be considered as a member of the Potyvirus family. This is also supported by the nucleic acid sequencing results, which indicated a conserved domain found in potyviral CP (pfam00767,Poty_coat, Potyvirus $\mathrm{CP}$ ). The nucleotide sequence estab- lished using the purified virus of isolate U06-123 also supported the viral nature of the disease agent, as did the electron microscopy, and fulfilled Koch's postulates in establishing that the U06-123 isolate originally isolated from wheat in the field was the causal agent of the disease.

As noted before, there were two ambiguities in the TOFMS- and computerpredicted sequence. An Asn residue in the sequence deduced from the nucleic acid cloning appears as Asp in the sequence determined by TOFMS. This deamidation occurs during sample preparation whenever there is a proximal downstream Gly residue; therefore, it is most likely an artifact of the protocol used to prepare the peptide for MS (17). The other ambiguity concerns the addition of an N-terminal Asp residue to the sequence deduced from nucleic acid clones. In this case, the evidence for an N-terminal Asp is compelling because the additional Asp residue appears not only in the MS measurement of the Nterminal peptide but also in all 10 of the $b$ ions generated by collision-induced dissociation (Table 6; Fig. 4) (16). Thus, the addition of the N-terminal Asp is likely the result of post-translational modification; such modifications of viral CPs has been documented by TOFMS for BMV (45), FoMV (35), HPV (44), JGMV (32), and WYHV (38).

The two approaches to determining the amino acid sequence of the CP have complementary strengths. On the one hand, it

\begin{tabular}{|c|c|c|c|c|c|c|}
\hline TriMV (NS) & VFHS & SGADQSGVVKD & QTGDKAEGSG & TKTEDPPNQT & TDPVNNPSNG & GNKDAPQNLN \\
\hline TriMV (TOFMS) & & EGADQSGVVKD & QTGDKAEGSG & TKTEDPPNQT & TDPVNNPSDG & GNKDAPQNLN \\
\hline SCSMV & 001 & GQGTQ-PPQD & QSTVASTSSS & TSATTTSQAE & SQTSGNLSN- & --------- \\
\hline & & & & $C P 1--->$ & $<--$ & $-C P 1 R$ \\
\hline TrimV (NS) & & ATVVTKSYTY & IPPIMKSLVT & IDTAKKMADY & TPPDALISTQ & ACTIEQFGRW \\
\hline TriMV (TOFMS) & & ATVVTKSYTY & IPPIMKSLVT & IDTAKKMADY & TPPDALISTQ & ACTIEQFGR \\
\hline SCSMV & 051 & TISQTMKSLY & VPPLVKSLKT & EAKAKQMMRY & TPPQALISSS & AASIRQFNDW \\
\hline TrimV (NS) & & ANGLGL & $\mathrm{SN}$ & $\pi \mathrm{N}$ & ASDEHKKLS & SWTKVNMTI \\
\hline TrIMV (TOFMS) & & & & & DEHKKLS & SWTKVNMTI \\
\hline SCSMV & 101 & ANTAAEGYGK & TIQQFTDEIL & PFWIYWCVVN & GATEENKTKP & KWTKAVFNLD \\
\hline TrimV (NS) & & QINLN & EGEAQTIYEM & SPMFDEAKPT & AVMRHFGA & LAYRWVKFS \\
\hline TriMV (TOFMS) & & & 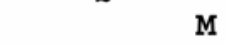 & SPMFDEAKPT & HFGA & LAYR \\
\hline SCSMV & 151 & GADGTEITVD & ENGPOIEFEM & GPMYRNAKPG & IRAIMRHFGE & LAYKWVQFS \\
\hline
\end{tabular}

\begin{tabular}{|c|c|c|c|c|c|c|}
\hline \multirow{2}{*}{\multicolumn{2}{|c|}{ TriMV (NS) }} & \multicolumn{4}{|c|}{ CP3--> } & \multirow[b]{2}{*}{ VRNQVII } \\
\hline & & AKRKPIIPHN & AIKAGLMDVT & YFPCCIDFVT & VDQLSPQEQN & \\
\hline TriMV (TOFMS) & & AKRKPIIPHN & ALKAGLMDVT & YFPCCIDFVT & VDQLSPQEQN & \\
\hline SCSMV & 201 & RSGKPIIPHN & AVKAGLTTPE & FYPCCIDFVM & VNILSPAEID & 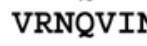 \\
\hline riMV (NS) & & SDTPRALFKH & AQRAGAGEED & TNLRRDDDAN & YGRTRVGGAM & FGTR \\
\hline riMV (TOFl & & SDTPRALFKH & AQRAGAGEED & TNLRRDDDAN & YGRTRVGGAM & FGTR \\
\hline SCSMV & 251 & PRMGRPLFRH & ALRAGG-DED & TDLRREDDAN & YGRTQIGGAH & FGRAC \\
\hline
\end{tabular}

Fig. 4. Triticum mosaic virus (TriMV) coat protein (CP) amino acid sequences as determined by computer translation of the nucleotide sequence (NS) and time-of-flight mass spectrometry (TOFMS). The TriMV sequences are aligned with the amino acid sequence of Sugarcane streak mosaic virus (SCSMV) (AY 193783); shared identities are highlighted in bold, gaps are represented by (-), and amino acids not determined by TOMFS are blank. Sites used for the design of primers CP1, CP1R, and CP3 are indicated above the sequence. VFHS/G at the amino terminus of the NS sequence indicates the putative NIaprotease cleavage site. G following VFHS marks the location of amino acid number one of the CP. Ambiguities between the initial TOFMS sequence and final sequence were verified by the NS. 
was possible to resolve the MS/MSderived sequence ambiguities only after the nucleic acid sequence was completed and a CP sequence had been derived from it: these ambiguities included amino acid mass identities ( $Q$ and AG, I and L), nearidentities (DAPQ and YTF, with only -3 mDA mass difference), and sequence transpositions (YS and SY). On the other hand, our initial peptide alignment speeded the determination of the nucleotide sequence significantly because it enabled the design of suitable primers for TriMV. The TOFMS measurements have the ability to examine the $\mathrm{CP}$ and its protease-generated fragments directly. They can determine the identity and position of amino acids not directly coded in viral RNA, which may arise by post-translational modification, such as the addition of an Asp amino acid residue at the $\mathrm{N}$-terminus.

TriMV is most closely related to SCSMV, a member of the genus Tritimovirus in the family Potyviridae $(10,11)$. However, it has been suggested that SCSMV be a new genus of the family Potyviridae $(14,26)$. TriMV differs from SCSMV by over $50 \%$, which greatly exceeds the $20 \%$ limit set to establish a new virus species based on nucleocapsid gene analysis (2). Also, wheat and barley were found to be infected by TriMV. The ability of TriMV to infect wheat emphasized a notable difference from SCSMV, which does not infect wheat (14). Although barley was identified as naturally infected by TriMV, it is not useful as a diagnostic host because it is also a host for WSMV (49). The identity of plant species other than wheat and barley naturally infected by TriMV remains unknown. Thus, the distance of TriMV's relationship from SCSMV supports the classification of TriMV as a new virus species.

The economic importance of natural infection of wheat by TriMV remains to be determined. Its ability to systemically infect wheat lines with resistance to WSMV is a concern $(40,42)$ but may be ameliorated if the incidence of the virus under field conditions is low. However, incidence is also a reflection of the vector and, as yet, no vector has been identified for TriMV. Thus, studies of incidence and distribution of TriMV in Kansas need to be conducted, as well as identification of the vector or vectors, host range, and yield of wheat lines currently planted to large acreages in Kansas; and the sequence of the entire virus should be pursued. We have proposed the name Triticum mosaic virus because infection of wheat by TriMV does not incite diagnostic symptoms other than a mosaic, and the name Wheat mosaic virus has been suggested for the pathogen causing High Plains disease of maize and wheat (51). Therefore, the genus name of wheat was selected in combination with the symptoms produced by infection in wheat.

\section{ACKNOWLEDGMENTS}

We thank J. Ackerman for his valuable assistance in virus purification, electrophoresis, ELISA, Western blotting, and greenhouse studies during this investigation.

\section{LITERATURE CITED}

1. Ahn, H. I., Yoon, J. Y., Hong, J. S., Yoon, H. I., Kim, M. J., Ha, J. H., Rhie, M. J., Choi, J. K., Park, W. M., and Ryu, K. H. 2006. The complete genome sequence of Pepper severe mosaic virus and comparison with other Potyviruses. Arch. Virol. 151:2037-2045

2. Berger, P. H., Barnett, O. W., Brunt, A. A., Colinet, D., Edwardson, J. R., Hammond, J. Hill, J. H., Jordan, R. L., Kashiwazaki, S., Makkouk, K., Morales, F. J., Rybicki, E., Spence, N., Ohki, S. T., Uyeda, I., van Zaayen, A., and Vetten, H. J. 2000. Family Potyviridae. Pages 703-724 in: Virus Taxonomy: Seventh Report of the International Committee on Taxonomy of Viruses. M. H. V van Regenmortel, C. M. Fauquet, D. H. L Bishop, E. B. Carstens, M. K. Estes, S. M. Lemon, J. Maniloff, M. A. Mayo, C. R. Pringle, and R. B. Wickner, eds. Academic Press, New York.

3. Brakke, M. K. 1971. Soil-borne wheat mosaic virus. In: Descriptions of Plant Viruses, No. 77. CMI/AAB, Kew, Surrey, UK.

4. Brakke, M. K., Skoop, R. N., and Lane, L. C. 1990. Degradation of wheat streak mosaic virus capsid protein during leaf senescence. Phytopathology 80:1401-1405.

5. Brandes, J. 1957. Eine elektronemikroskopische schnellmethode sum nachweis fadenund stabehenformiger viren, insbesondere in kartoffeldunkelkeimen. Nachrbl. Deut. Pflanzenschutzdientz (Braunschweig) 9:151152.

6. Brandes, J., and Wetter, C. 1959. Classification of elongated plant viruses on the basis of particle morphology. Virology 8:99-115.

7. Bollig, D. M., and Edelstein, S. J. 1991. Immunobloting. Pages 181-208 in: Protein Methods. Wiley-Liss, New York.

8. Clark, M. F., and Adams, A. N. 1977. Characteristics of the microplate method of enzymelinked immunosorbent assay for the detection of plant viruses. J. Gen. Virol. 34:475-483.

9. Haley, S. D., Martin, T. J., Quick, J. S., Seifers, D. L., Stromberger, J. A., Clayshulte, S. R., Clifford, B. L., Peairs, F. B., Rudolph, J. B., Johnson, J. J., Gill, B. S., and Griebe, B. 2002. Registration of CO960293-2 wheat germplasm resistant to Wheat streak mosaic virus and Russian wheat aphid. Crop Sci. 42:1381-1382.

10. Hall, J. S., Adams, B., Parsons, T. J., French, R., Lane, L. C., and Jensen, S. G. 1998. Molecular cloning, sequencing and phylogenetic relationships of a new potyvirus: sugarcane streak mosaic virus and a reevaluation of the classification of the Potyviridae. Mol. Phylogenet. Evol. 10:323-332.

11. Hema, M., Joseph, J., Gopinath, K., Sreenivasulu, P., and Savithri, H. S. 1999. Molecular characterization and interviral relationships of a flexuous filamentous virus causing mosaic disease of sugarcane (Saccharum officinarum) in India. Arch. Virol. 144:479-490.

12. Hema, M., Kirthi, N., Sreenivasulu, P., and Savithri, H. S. 2003. Development of recombinant coat protein antibody based IC-RT-PCR for detection and discrimination of sugarcane streak mosaic virus isolates from southern India. Arch. Virol. 148:1185-1193.

13. Hema, M., Sreenivasulu, P., Gopinath, P., Kiranmai, G., and Satyanarayana, T. 1997. Partial characterization of a potyvirus causing mosaic disease of sugarcane in Andhra Pradesh. Indian J. Virol. 13:125-129.

14. Hema, M., Sreenivasulu, P., and Savithri, H. S. 2002. Taxonomic position of sugarcane streak mosaic virus in the family Potyviridae. Arch. Virol. 147:1997-2007.
15. Jensen, S. G., Lane, L. C., and Seifers, D. L. 1996. A new disease of maize and wheat in the high plains. Plant Dis. 80:1387-1390.

16. Kinter, M., and Sherman, N. E. 2000. Protein Sequencing and Identification Using Tandem Mass Spectrometry. Wiley Interscience, New York.

17. Krokhin, O. V., Antonovici, M., Ens, W., Wilkins, J. A., and Standing. K. G. 2006. Deamidation of -Asn-Gly-sequences during sample preparation for proteomics: consequences for MALDI and HPLC-MALDI analysis. Anal. Chem. 78:6645-6650.

18. Krokhin, O. V., Craig, R., Spicer, V., Ens, W., Standing, K. G., Beavis, R. C., and Wilkins, J. A. 2004. An improved model for prediction of retention times of tryptic peptides in ion pair reversed-phase HPLC: its application to protein peptide mapping by off-line HPLCMALDI MS. Mol. Cell. Proteomics 3:908-919.

19. Krokhin, O. V., Spicer, V., Standing, K. G., Wilkins, J. A, and Ens, W. 2006. "SMART" (Search by Mass and Retention Time) - a new tool for HPLC-MALDI MS peptide mass fingerprinting. Poster 533, 54th ASMS Conference on Mass Spectrometry and Allied Topics, Seattle.

20. Laemmli, U. K. 1970. Cleavage of structural proteins during the assembly of head of bacteriophage T4. Nature 227:680-685.

21. Lane, L. C. 1978. A simple method for stabilizing protein-sulfhydryl groups during SDSgel electrophoresis. Anal. Biochem. 86:655664.

22. Lane, L. C. 1986. Propagation and purification of RNA plant viruses. Methods Enzymol. 118:687-696.

23. Lengkeck, V. H. 1979. Wheat Virus Disease in Southwestern Kansas. Coop. Ext. Rep. Kansas State University, Manhattan.

24. Loboda, A. V., Krutchinsky, A. N., Bromirski, M., Ens, W., and Standing, K. G. 2000. A tandem quadrupole/time-of-flight mass spectrometer with a matrix-assisted laser desorption/ionization source: design and performance. Rapid Commun. Mass Spectrom. 14:1047-1057.

25. Louie, R., Seifers, D. L., and Bradfute, O. E. 2006. Isolation, transmission and purification of the High Plains virus. J. Virol. Methods 135:214-222.

26. Rabenstein, F., Seifers, D. L., Schubert, J., French, R., and Stenger, D. C. 2002. Phylogenetic relationships, strain diversity and biogeography of tritimoviruses. J. Gen. Virol. 83:895-906.

27. Rao, G. P., Singh, M., Gaur, R. K., and Jain, R. K. 2004. Antigenic and biological diversity among sugarcane mosaic isolates from different geographical regions in India. Indian $\mathrm{J}$. Biotechnol. 3:542-545.

28. Rochow, W. F. 1970. Barley yellow dwarf virus. In: Descriptions of Plant Viruses, No. 4. CMI/AAB, Kew, Surrey, UK.

29. Seifers, D. L. 1992. Partial characterization of a Colorado isolate of Agropyron mosaic virus Plant Dis. 76:564-569.

30. Seifers, D. L. 2006. Identification of variants of the High Plains virus in Kansas. (Abstr.) Phytopathology 96:S106.

31. Seifers, D. L., and Caceres, J. 1988. Titer variation in infected sorghum differing in resistance to maize dwarf mosaic virus strain-B. Phytopathology 78:208-212.

32. Seifers, D. L., Haber, S., Ens, W., She, Y.-M. Standing, K. G., and Salomon, R. 2005. Characterization of a distinct Johnsongrass mosaic virus strain isolated from sorghum in Nigeria. Arch. Virol. 150:557-576.

33. Seifers, D. L., Handley, M. K., and Bowden, R. L. 1993. Sugarcane mosaic virus strain maize dwarf mosaic virus $\mathrm{B}$ as a pathogen of eastern gamagrass. Plant Dis. 77:335-339.

34. Seifers, D. L., Harvey, T. L., and Bowden, R. 
L. 1995. Occurrence and symptom expression of American wheat striate mosaic virus in wheat in Kansas. Plant Dis. 79:853-858.

35. Seifers, D. L., Harvey, T. L., Haber, S., She, Y.M., Chernushevich, I., Ens, W., and Standing, K. G. 1999. Natural infection of sorghum by Foxtail mosaic virus in Kansas. Plant Dis. 83:905-912.

36. Seifers, D. L., Harvey, T. L., Kofoid, K. D., and Stegmeier, W. D. 1996. Natural infection of pearl millet and sorghum by Wheat streak mosaic virus in Kansas. Plant Dis. 80:179-185.

37. Seifers, D. L., Harvey, T. L., Martin, T. J., and Jensen, S. G. 1997. Identification of the wheat curl mite as the vector of the High Plains virus of corn and wheat. Plant Dis. 81:1161-1166.

38. Seifers, D. L., Harvey, T. L., Martin, T. J., She, Y.-M., Ens, W., Standing, K. G., Salomon, R., and Gera, A. 2005. Association of a virus with wheat displaying yellow head disease symptoms in the Great Plains. Plant Dis. 89:888895.

39. Seifers, D. L., and Martin, T. J. 1988. Correlation of low level of Wheat streak mosaic virus resistance in Triumph 64 wheat with low virus titer. Phytopathology 78:703-707.

40. Seifers, D. L., Martin, T. J., Harvey, T. L., and Gill, B. S. 1995. Temperature sensitivity and efficacy of wheat streak mosaic virus resistance derived from Agropyron intermedium. Plant Dis. 79:1104-1106.

41. Seifers, D. L., Martin, T. J., Harvey, T. L., and Haber, S. 2007. Temperature-sensitive Wheat streak mosaic virus resistance acquired from KS03HW12 wheat. Plant Dis. 91:1029-1033.

42. Seifers, D. L., Martin, T. J., Harvey, T. L., Haber, S., and Haley, S. D. 2006. Temperature sensitivity and efficacy of Wheat streak mosaic virus resistance derived from C0960293 wheat.
Plant Dis. 90:623-628.

43. Seifers, D. L., Salomon, R., Marie-Jeanne, V., Alliot, B., Signoret, P., Haber, S., Loboda, A., Ens, W., She, Y.-M., and Standing, K. G. 2000. Characterization of a novel potyvirus isolated from maize in Israel. Phytopathology 90:505513.

44. Seifers, D. L., She, Y.-M., Harvey, T. L., Martin, T. J., Haber, S., Ens, W., Standing, K. G., Louie, R., and Gordon, D. T. 2004. Biological and molecular variability among High Plains virus isolates. Plant Dis. 88:824-829.

45. She, Y.-M., Haber, S., Seifers, D. L., Loboda, A., Chernuschevich, I., Pereault, H., Ens, W., and Standing, K. G. 2001. Determination of the complete amino acid sequence of the coat protein of Brome mosaic virus by time-offlight mass spectrometry. J. Biol. Chem. 276:20039-20047.

46. She, Y.-M., Seifers, D. L., Haber, S., Ens, W., and Standing, K. G. 2004. Characterization of the agent of 'High Plains Disease': mass spectrometry determines the sequence of the disease-specific protein. J. Biol. Chem. 279:488494.

47. Shevchenko, A., Chernushevich, I., Ens, W., Standing, K. G., Thomson, B., Wilm, M., and Mann, M. 1997. Rapid de novo peptide sequencing by a combination of nanoelectropray, isotopic labeling and a quadrupole/time-offlight mass spectrometer. Rapid Commun. Mass Spectrom. 11:1015-1024.

48. Shevchenko, A., Sunyaer, S., Loboda, A., Shevchenko, A., Bork, P., Ens, W., and Standing, K. G. 2001. Charting the proteomes of organisms with unsequenced genomes by MALDI-quadropole time-of-flight mass spectrometry and BLAST homology searching. Anal. Chem. 73:1917-1926.
49. Sill, W. H., Jr., and Connin, R. V. 1953. Summary of the known range of the wheat streak mosaic virus. Trans. Kans. Acad. Sci. 56:411417.

50. Sim, T., IV, Willis, W. G., and Eversmeyer, M. G. 1988. Kansas plant disease survey. Plant Dis. 72:832-836.

51. Skare, J. M., Wijkamp, I., Denham, I., Rezende, J. A. M., Kitajima, E. W., Park, J.W., Desvoyes, B., Rush, C. M., Michels, G., Scholthof, K.-B. G., and Scholthof, H. B. 2006. A new eriophyid mite-borne membraneenveloped virus-like complex isolated from plants. Virology 347:343-353.

52. Slykhuis, J. T. 1955. Aceria tulipae Keifer (Acrina:Eriphidae) in relation to the spread of wheat streak mosaic. Phytopathology 45:116128.

53. Slykhuis, J. T. 1976. Wheat spindle streak mosaic virus. In: Descriptions of Plant Viruses, No. 167. CMI/AAB, Kew, Surrey, UK.

54. Standing, K. G. 2003. Peptide and protein de novo sequencing by mass spectrometry. Curr Opin. Struct. Biol. 13:595-601.

55. Towbin, H. T., Staehelin, T., and Gordon, J. 1979. Electrophoretic transfer of proteins from polyacrylamide gels to nitrocellulose sheets: Procedure and some applications. Proc. Natl Acad. Sci. USA 76:4350-4354.

56. van Regenmortel, M. H. V., Fauquet, C. M. Bishop, D. H. L, Carstens, E. B., Estes, M. K., Lemon, S. M., Maniloff, J., Mayo, M. A. Pringle, C. R., and Wickner, R. B. 2000. Virus Taxonomy: Seventh Report of the International Committee on Taxonomy of Viruses. Academic Press, New York.

57. Willis, W. G. 1981. The 1981 Wheat Streak Mosaic Epidemic in Kansas. Coop. Ext. Rep. Kansas State University, Manhattan. 